\title{
Equivocal Connections: Fonseca Cardoso and the Origins of Portuguese Colonial Anthropology
}

\author{
Ricardo Roque \\ Instituto de Ciências Sociais, Universidade de Lisboa \\ 2022
}

POUR CITER CET ARTICLE

Roque, Ricardo, 2022. "Equivocal Connections: Fonseca Cardoso and the Origins of Portuguese Colonial Anthropology", in Bérose - Encyclopédie internationale des histoires de l'anthropologie, Paris.

URL Bérose : article2534.html

Publication Bérose : ISSN 2648-2770

(c) UMR9022 Héritages (CY Cergy Paris Université, CNRS, Ministère de la culture)/DIRI, Direction générale des patrimoines et de l'architecture du Ministère de la culture. (Tous droits réservés).

Votre utilisation de cet article présuppose votre acceptation des conditions d'utilisation des contenus du site de Bérose (www.berose.fr), accessibles ici.

Consulté le 18 janvier 2022 à 15 h53min

Publié dans le cadre du thème de recherche «Histoire de l'anthropologie et archives ethnographiques portugaises (19e-21e siècles)», dirigé par Sónia Vespeira de Almeida (CRIA/NOVA FCSH, Lisbonne) et Rita Ávila Cachado (CIES-IUL, Lisbonne).

This article is about the equivoques of anthropology's colonial encounter as well as the story of intellectual artefacts. [1] It addresses an old debate on the genealogy of anthropological knowledge, at the core of which is a shared assumption: anthropologists and historians today perceive the history of anthropology as intertwined with colonial history. Few, if any, anthropologists or historians would disagree that the anthropology of non-Western peoples is genealogically embedded in imperial expansion or colonial contexts, and that we can hardly imagine colonial power without some sort of anthropological knowledge as bedside company. It is also true that this assumption has not been at all devoid of strong moral convictions about the evil nature of colonialism and its friendly anthropologies, a moral impetus particularly evident in earlier approaches to the subject in the 1960s and '70s. Since that time, though, with the exception of Talal Asad's seminal assessment in 1973, historians have given it little systematic attention as a subject in its own right. [2] As George Stocking noted in 1991, the 'assumption that anthropology was linked to Western colonialism' seems to have survived in the professional culture of anthropologists more in the form of a 'commonplace of disciplinary discourse' than as a 'serious interest in the history of anthropology in colonial context'. [3] Although the Portuguese case has been entirely left out of this picture by English literature, Stocking's remarks apply to the Portuguese 
anthropological discourse since the 1970s. Having its professional identity closely associated with political opposition to the authoritarian Estado Novo regime, Portuguese social anthropology, born into institutional autonomy out of the April Revolution in 1974, has been eager to accuse earlier generations of (physical) anthropologists of racial prejudice and complicity with the imperial state. Very few have undertaken a serious and critical historical approach to such a pervasive disciplinary assumption. [4]

Anthropology's colonial history retains its attractive power, but the commonplace does not satisfy historians and anthropologists anymore. The study of the roots of colonial anthropology or, more specifically, ethnography, has received careful and novel critical attention. Pels and Salemink's Colonial Ethnographies of 1994 and two volumes of 1999 are devoted to exploring and re-working the agenda opened up by Asad's volume. [5] Crucial in the new impulse for objectifying anthropology and colonialism are Pels and Salemink's programmatic formulations. Restoring Stocking's historicist appeal to debunk the 'presentist' bias of disciplinary history, Pels and Salemink argue for a wider and nondisciplinary understanding of practitioners and forms of anthropology. [6] The genealogy of ethnographic theories and methods is now regarded as located in the heterogeneous and plural realms of 'colonial practice' and 'colonial subjects', well beyond the boundaries of the academic profession. Colonial contexts such as missionary work, settlement, war and pacification, government or trade re-emerge as crucial moments and agents of anthropology's past. [7] At the same time, their idea of a 'practical history of anthropology' offers an important attempt to depart from the literary reductionisms of discourse and intertextual analysis. We are asked to turn our energies instead to the study of practices, locating text in its situations of (co)production and 'material mediations'. [8]

However, as often occurs with every programmatic formula, not all is equally developed by other scholars, even by the proponents themselves. The effort to shake disciplinary histories seems to have come to the fore, while other lines of enquiry appear to remain in its shadow. Historians of anthropology are especially concerned with reviewing the canons of genealogical narratives and restoring its 'excluded ancestors'. [9] In this sense, one may recognize that Pels and Salemink's volumes are successful attempts to expose the biases of disciplinary genealogies, as well as to provide new understandings of non-academic professionals and practices in their historical contexts of ethnographic production. But there is at least one important aspect in the 'fourth thesis' of Pels and Salemink's programme which historians, and the authors themselves, have not investigated.[10] I refer to the neglect of practices of consumption, by which one can follow the ways anthropological inscriptions and objects are put (or not) to colonial use. As they themselves wrote, elaborating on reductionisms of Edward Said's approach to the power of orientalist representations: 'before assuming that the content of the ethnographic text is an example of intellectual colonization of "others", one first has to analyse the ways in which it was consumed by different audiences, both within and outside of the colonial situation'. [11] However, the prospect for a joint exploration of the production and reception of texts is omitted in Pels and Salemink's programme. It appears to have been displaced by the debunking of professional genealogies 
in the authors' programme. The practical history of anthropology they propose turns, in fact, into an analysis of the contexts that preclude and situate the writing of the anthropological texts, an approach they epitomize in the analytical sequence of préterrain, ethnographic occasions and ethnographic traditions. [12] Yet, one still knows very little about how anthropological textual artefacts are actually read and why and how they are used, or not, by colonial agents. [13] Thus, in this sense a question remains to be asked: how do anthropological texts become, and fail to become, connected to colonial projects, events and materials across their discontinuous processes of production and reception?

This article tries to address this question, offering an attempt to discuss the history of production and consumption of textual anthropological artefacts as unstable trajectories of circulation materially performed in multiple sites. In so doing, I will try critically to retell the genealogical story of a scientific discipline: colonial anthropology. This story takes us to the particular experience of Portuguese anthropology aligned with a physical and racialist tradition. In 1934, Artur da Fonseca Cardoso (1865-1912), an army captain who died from malaria in Portuguese Timor in 1912, was celebrated as the 'founding father' of colonial anthropology in Portugal. The occasion for this celebration was the First Congress of Portuguese Colonial Anthropology, held in Porto as part of a first national exhibition entirely devoted to the Portuguese colonies. In the opening pages of the congress proceedings, Cardoso's ceremonial portrait, captioned 'Fonseca Cardoso, iniciador da Antropologia Colonial Portuguesa', was exhibited as an icon of the discipline. He was acknowledged in a laudatory biographical sketch: 'Fonseca Cardoso', Mendes Correia wrote, 'was undeniably one of the most eminent figures of Portuguese anthropology. [...] In Portuguese India he made a magnificent study on 'O Indígena de Satari' [...] Unfortunately, death did not let him finish his splendid work.' [14]

To complement this narrative, one of Cardoso's publications was taken as the founding bibliographical event of the science of colonial anthropology in Portugal: a twelve-page article discussing the anthropometry and racial types of Satari's native population, an inland district of Goa, former Portuguese colony in India. [15] The article, 'O Indígena de Satari. Estudo antropológico' was published in 1897 in a Portuguese scientific journal, Revista de Ciências Naturais e Sociais, but fieldwork was carried out while Cardoso campaigned as military officer in the colonial 'pacification' of the Ranes' rebellion of 1895-96, in Goa. [16] This 1930s narrative produced a genealogy and a founding father for a scientific discipline explicitly linking anthropology and the imperial project, which would exist in Portugal under the heading 'colonial anthropology' for about fifty years. Both man and text were thought of as the origins of Portuguese colonial anthropology.

Although this story concerns the trajectory of a specific intellectual artefact (the text ' $O$ Indígena de Satari') and the heroic tale of its author, as well as the particular experience of Portuguese anthropologists, it is hoped this will contribute to the broad debate on anthropology's colonial roots to which I referred at the beginning of this article. [17] It does so in three principal strands of argument. Firstly, and most immediately, it helps to fill in a gap 
on the subject of historiography, restoring, as it were, an 'excluded ancestor' of Western colonial anthropology. Much that is known and discussed about anthropology (especially ethnography) and colonialism concerns the British colonial experience, and to a minor extent perhaps the French, German, Dutch, Russian, and even Japanese experience. [18] Portuguese imperial experience has been excluded in this respect. [19] For these reasons I hope to contribute to putting the Portuguese case on the map. Secondly, I would like to add my voice to those who critically explore the genealogical trope of anthropology and colonialism's association by underlining some of the possible consequences of taking into account both production and consumption as jointly constitutive of the colonial condition of anthropological texts. I argue that the above notion of a practical history of anthropology, which I think is a fruitful one, should be extended to the practices of consumption. As such, consumption has to be understood as a set of practices actively involved in producing the texts. Anthropologists, historians and sociologists of reading have long stressed that readers and every situated material or narrative practice that enacts a text have an important role to play in the conduct of discourses through time. [20] I thus propose to follow anthropological texts as intellectual artefacts along their various locations of material and practical production - not only préterrain, occasions of contact in the field, or cultural resources, but also the processes of circulation of the text, that is the temporally emergent practical performances of intellectual artefacts in their multiple contexts of use, within and outside of the colonial realm.

Once one concentrates the analysis on the full practical process of the production-reception of anthropological artefacts we will be in a position to problematize the way anthropology and colonialism are imagined as historically and locally connected.[21] Thus, thirdly, this text argues that anthropological artefacts and colonial elements have to be re-networked through processes of translations by the participants themselves, if anthropology is to emerge as associated or disassociated with colonialism. [22] I am thus suspicious of the assumption that 'anthropology and empire were never separated', which critical historians such as Pels and Salemink have difficulty in denying, at least 'in principle'. [23] By contrast, it is my intention to enhance the fluctuant process by which anthropology becomes and fails to become colonial. The irregularity, precariousness and contradiction inscribed in the association between anthropology and colonialism can be approached with the insightful notion of 'partial connections' put forward by Donna Haraway and Marilyn Strathern. [24] 'Partial connections', Strathern says, 'require images other than those taxonomies or configurations that compel one to look for overarching principles or for core or central features. [...] they would be maps without centers and genealogies without generations'. [25] A central argument of this essay is that connections between anthropology and colonialism are partial - but, also, that they can be equivocal. In what follows, I will try to give evidence of the unsteady binding of anthropology and colonialism across time, as well as of the equivocal translations along which connections or disconnections between anthropological science and colonial projects are performed. I hope to show that the establishment of these dis/connections depend on the mutable intervention of a disparate collective of participants 
and contingencies, so that in the specific case of Fonseca Cardoso and 'O Indígena de Satari' anthropology's attachment to colonialism emerges as a chain of equivocal connections.

I develop these arguments in four sections, which roughly follow a chronological order. I begin in the years prior to Cardoso's move to Goa in 1895, and try to set his connection to anthropology in the context of his scientific programme, social relations and patriotic ideology. It describes Cardoso's strong involvement in a programme of anthropology as an attempt to regenerate the nation and unveil the ethnogeny of Portugal. I then move to the imperial setting where Cardoso was forced to participate as a consequence of his military profession: the 'pacification' campaign of 1895-96. Here, I try to show the weaknesses of Portuguese imperial power in the peculiar conflict with the Ranes of Satari, one in which the range of possibilities for Cardoso to succeed with anthropometric fieldwork was, in fact, very restricted. Generally, colonial power relations, I argue, did not provide a supportive structure for the practice of anthropology. The third section focuses on the ambivalent contingencies that led to the imprisonment of forty-four Satarians, later subjected to anthropometric observation. I here argue that Fonseca Cardoso took advantage of an equivocal demonstration of imperial inefficiency to enlist living subjects for anthropological study. I finally attempt to follow the practical production of the text throughout the writing and circulation of 'O Indígena de Satari' in succeeding years, from 1897 to 1934. I here confront contemporary silences, Cardoso's strategies of scientific credibility and later genealogical appropriations of him and his text for the professional benefit of a new generation of anthropologists. Colonial dis/connections of text and author were put in relief or cut away as they were performed in often contrasting narratives on anthropology, empire and the nation.

\section{Anthropology at Home: Fonseca Cardoso and Anthropology in Portugal}

Fonseca Cardoso was born in the city of Porto, northern Portugal, into a family with strong military traditions. He did not disappoint the social and professional expectations of his parents and relatives, and soon followed a military career as army officer. Yet, his heart and personal vocation pointed elsewhere. In his early twenties, along with a group of young intellectual friends, he aspired to replicate in Portugal the success and astonishing promise of evolutionism and, particularly, the new positive and empirical sciences of archaeology, palaeoethnology and anthropology as they were put forward by French scholars in the Société d'anthropologie de Paris and related institutions. [26] It is worth noting that our contemporary socio-cultural meaning of anthropology hardly applies to the understanding which the term 'anthropology' had for Cardoso and his group. Following Paul Broca and Paul Topinard, the science of anthropology (anthropologie) was primarily a comparative anatomy of races, the 'natural history of mankind', the universal attempt to display all peoples around the world in a table of racial types. Anthropometry (the measuring and mathematical depiction of living bodies) and craniology (the study of skulls) were deemed to provide reliable anthropological matters of fact parallel to the achievements of laboratory science and 
classical natural history.

Inspired by French enthusiasm (personally expressed by Paul Topinard himself in correspondence with the Portuguese group), [27] in 1887 Cardoso and his friends created a scientific society, Sociedade Carlos Ribeiro, and a scientific journal devoted to the natural and social sciences, Revista de Ciências Naturais e Sociais, where Cardoso would later publish his Goan work. [28] Despite the fascination for French models, the Sociedade Carlos Ribeiro group, among them the celebrated pioneers of Portuguese anthropology Rocha Peixoto and Ricardo Severo, close friends of Cardoso, aimed to replicate the French anthropological programme in Portugal with a slight yet important adjustment. [29] Notwithstanding the appeal for extra European empirical fieldwork of Topinard's version of the French programme, the Portuguese were interested in restricting it to a scientific programme of anthropology at home, an interest that was particularly consistent with the agenda set out by the previous generation of Portuguese ethnologists. [30] Attachment to nationalistic language turned French anthropologie into a form of tracing the racial genealogy of the Portuguese people, an instrument of patriotic resurgence. Many people believed that human and natural sciences should serve the regeneration of Portugal in the present by showing its egregious national roots in the past. Indeed, Cardoso's ideological politics of anthropology can better be inscribed within a patriotic discourse on national identity and the risks of national decadence (one strongly present in nineteenth-century Portuguese intellectual traditions) than within a discursive field focused on colonial projects. [3I] The proper objects of this patriotically-oriented anthropology were the present inhabitants of Portugal themselves and their ancestors. Populations other than the peoples originally settled in European Portugal were not part of the anthropological project as it was intentionally advocated by Fonseca Cardoso and his friends in Porto back in the 1880s and early' 90 s.

Cardoso's changing scientific interests show this point very clearly. Initially devoted to archaeology, he shifted his interest to the methodological core of Paul Topinard's anthropologie: anthropometric methods and racial typification. [32] On the eve of 1890 he was keen on doing an anthropometric chart of Minho (a rural district in Northern Portugal) as a contribution to the racial genealogy of Portugal. From 1893 to the Goan crisis of 1895, Cardoso was planning the study of two thousand male soldiers, thus taking advantage of compulsory state military recruitment in the north. Cardoso was not an academic, but in a way, could think himself lucky for being both a trained anthropologist and a career army officer (he would become a captain in 1902). In accordance with other contemporary practitioners of military anthropology in Europe, he would put his hierarchical position in the army to anthropological profit. [33] Using his institutional position, he had access either directly to hundreds of obedient and manageable living bodies - the recruits - or indirectly to the army anthropometric registers, which he would collect from other fellow army officers sympathetic to his scientific project. In 1893, he vividly expressed his enthusiasm in several letters to his friend and ethnographer José Leite de Vasconcelos, by that time a respected scholar and near to becoming the first director of the national ethnological museum: 
At present I am crossing out registers for the study of the stature of the Minho man as a contribution to the general and anthropological study of our people and as material for the preparation of the Portuguese stature chart. This should already have been done, following the example of those drawn up in France, Germany, etc. For this study I will use the existing recruitment register in each regiment, taking advantage of this year's inspection that is being done in my regiment. [34]

In 1894, in order to come to terms with the Minho project he ordered from France Topinard's caisse anthropométrique ('anthropometrical box'), a portable set of anthropometric instruments uniquely produced in Paris by special order. In 1895 he stressed how French instruments were intended to support the anthropometry of Minho's soldiers:

Please be aware, my good doctor, that I currently possess an anthropometric box from the Collin house which has just arrived from Paris. In this box I have all the instruments necessary for anthropometric measurements. It contains: a thickness caliper, a slide caliper, an anthropometric board, an anthropometric slide, a cephalometric square, a tape measure, two coloured pencils, etc. The case is comfortable and small; the instruments can be disassembled to be put in the case and taken on travels. All very well made and a perfect fit. As you can see I am pleased with the anthropometric box and next year I intend to start measuring 800 men from the district of Viana in Minho who are going to the inspection for recruitment. I also intend to measure some women, which should be somewhat difficult, given the suspicious temperament of our people. We shall see. [35]

But an unexpected change of circumstances would interrupt this scientific project. Despite Fonseca Cardoso's plans, he would not be able to realize his anthropometry project in northern Portugal at that time. He was dispatched to India instead, where a distant imperial crisis obliged him to do his patriotic duty as a military officer. He was compulsorily called to serve in the 'pacification' campaign in Goa and fight the Ranes of Satari. So the story of Fonseca Cardoso's move to anthropological fieldwork in the colonies emerges as an equivocal event in his life: a severe break in his personal and collective plans, an emotionally painful separation from his wife and children, and an event blocking the course of action he expected to follow in the science of anthropology in Portugal. [36] This equivocation would lead Cardoso to translate a programme of national anthropology into a programme of the natural history of human races, as will be seen below.

\section{Colonial Situations: Portuguese Empire and the 'Pacification' of Goa}

Let us move on from the account of Cardoso and anthropology to Portuguese imperial expansion in Goa in 1895. By describing the events and power relationships involved in this colonial process, we will be in a better position to understand how anthropological fieldwork took place in Goa. In fact, it appears at first sight that the 'pacification' of Goa was the military event that, despite preventing Cardoso's anthropology project in Portugal, allowed 
him to practise anthropometry in the colonies.

In 1895, Portuguese nationalist imperial appetites were at their peak. Goa, an old Portuguese colony and jewel of the oriental empire, was shaken by an indigenous uprising that resulted in Portuguese colonial authorities organizing an important military expedition. Although it had long since lost its economic importance in comparison to Brazil and Africa, Goa still held crucial symbolic and ideological significance in the emerging patriotic imperialist language. It stood as a landmark of imperial glory and great national deeds undertaken by heroic men (Afonso de Albuquerque, the conqueror; Vasco da Gama, the navigator), and a model for a newcoming age of the Portuguese empire. A series of events perceived as outrageous to the emerging nationalistic rhetoric of imperial hegemony led the Portuguese to raise arms against the Goans. The causal chain leading to the Goan revolt was long and complex. An explosive cocktail of events resulted in a difficult situation for the colonial governor: aggressive anti- Portuguese and proto-nationalist native political activity (the so-called nativismo); inability to extend state control to inland territories; conflicts between state, 'narcornins' (indigenous administrative officials), village communities, and landowner elites in Satari (particularly the Ranes, a powerful caste-like elite of warriors and landowners claiming Rajput lineage); and, finally, the desertion of Marata soldiers from the colonial police to avoid fighting in Mozambique. On October 1895 the situation took on dramatic proportions. Loyal colonial troops in Goa felt incapable to oppose the fierce activity of hundreds of well-armed 'indigenous rebels' coming down from the northern province of Satari under the command of the Ranes. Within a few weeks after the Maratas' desertion, Europeans were trapped in the besieged capital, Panaji, while attempting to escape. [37]

As strange as it might seem, Goa was far from being a perfectly colonized, pacified, and effectively occupied territory, despite the four centuries of Portuguese presence as traders, official administrators, military and missionaries. The fact that the Goan revolt was headed by the Ranes, later spreading from Satari to other districts, also caused the Portuguese to face the revolt with particular anxiety. The district of Satari in Novas Conquistas was an ungovernable piece of colonial land. [38] The Ranes, who to all intents and purposes controlled the district, had a long history of fighting against the Portuguese dating back to the mid-eighteenth century, such that colonizers had been unable to impose their will. [39] After a century of undignified battles against the Ranes, imperial anthropological stereotypes characterized them as ferocious, 'terrible', treacherous and wild, feudal and uncivilized warriors, who ruled over 'savage and ignorant' rural people. [40] The Ranes represented in Goa the most dreadful enemies of the empire, and many considered them to be the ultimate cause of the crisis, the target of violence and military punishment. But the Portuguese imperial presence here was weak; control was partially delegated to local groups, and the balance of power between them and the Ranes was precarious.

Believing the empire at risk, a large military force, under the command of the king's son himself, Infante D. Afonso Henriques, was sent to fight the Ranes in India. From north to south, Portuguese officers and men were called up to serve in distant Asia. Most had never 
set foot outside their rural villages. Artur da Fonseca Cardoso was one of six hundred men, including infantry, cavalry, medics and staff officers, who set sail for Goa on 21 October, following an epic departure from Lisbon. [41] Things would not run smoothly, however, despite patriotic expectations. The expedition faced problems from the outset: the contingency of events, the geography of the area (the mountainous terrain and dense forests of Satari), the tropical climate and, finally, the agency of the enemy would all put imperial pacification at risk.

A massive force of infantry marched north to occupy Satari, burn the villages as punishment, and defeat the Ranes' armies and put their leaders in prison. But after months chasing the rebels there had been virtually no direct confrontation. After a full month of campaigning in India there had been only one brief encounter with a pugnacious group of rebels, 'the only group of rebels that was found until today'. [42] Indeed, when the expedition finally reached Satari, they found the villages uninhabited. Moreover, the rebels employed guerrilla tactics, sometimes firing on the troops from the tops of canyons, or from within dense woods, and then disappearing into the forests out of reach of the invaders. Such tactics - brief assaults and then immediate withdrawals - gave the Portuguese the impression of confronting mobile and invisible enemies, and reinforced the fear of a frustrated military outcome. In a short letter to a local newspaper in Portugal, one soldier confessed this: 'The enemy has fled, and there has never been any fighting, for he is buried in the mountains well close to us, in the grass he watches our movements and there he crawls like the snake.' [43] Captain Gomes $\mathrm{da}$ Costa, a controversial and active participant in the events, described the general feelings about the expedition in his memoirs some years later:

In which direction would the enemy gather? This was the eternal problem. Finding this out always caused immense difficulty, and when, at the end of an insane labour, it was found, it dispersed, disappeared, vanished, only to be reunited at a point fixed beforehand, and which took us several more days to discover. This was always the history of the operations in India. [44]

In May 1896 the Infante, Fonseca Cardoso, and the entire expedition returned to Portugal, frustrated, exhausted, and with few, if any, practical results. Although some Portuguese newspapers blindly celebrated the glorious return of the soldiers to Lisbon, more clearminded contemporaries evaluated the Goan expedition as an imperial failure. Another year of battles and political persecutions passed before the conflict was officially ended. In fact, the Portuguese only achieved this by shifting from their former strategy of submission to military force to a diplomatic negotiation of their authority in Satari. After negotiation, Maratas and Ranes could have thought themselves victorious, for they were granted total amnesty, their old rights over their lands preserved, they were offered prestigious posts in the colonial army, and it was agreed they would never have to leave Goa to fight in distant Africa.[45] 


\section{Fieldwork and Imperial Equivoques: Anthropometric Occasions in Coa}

Up to this point I have talked separately about empire, war, 'pacification' and anthropology. The intellectual artefact, 'O Indígena de Satari', is absent, or at least in the background. I have done this simply because until a certain moment in Goa in 1895, the anthropology of Fonseca Cardoso and Portuguese colonialism were separate and distinct historical and sociological events. While focusing on the interests and scientific programme of Cardoso, we saw how anthropological theory and practice was not 'colonial' prior to 1895; it was not connected to imperial projects or motivations, and was seen as an endeavour at home enclosed in nationalistic language. No notion of a study of Indian people had hitherto existed. We have also seen empire being enacted in colonial situations as negotiated, uncertain, non-hegemonic practical work. Moreover, the expedition collective seen in action above did not include the science of anthropology as a strategic device for the construction of imperial order in Satari. Indeed, with a severe lack of intelligence on the activities of the rebels, chief politicians and military heads developed their own set of technologies of knowledge. The commander in chief, Infante D. Afonso, instituted a special company of Sipais under his direct command (Companhia de Sipais do Senhor Infante), composed of native troops and allied Ranes. A central function of the Sipais was to provide reliable information about the location and movements of the rebels - espionage. But this excluded information on racial and anthropometric anthropology or ethnography, due most likely to the fact that this sort of information was of no use in tracking down the enemy. Anthropometry was not important to pacification; it would not help to resolve any of the imperial and military problems during the crisis in Goa. For these reasons one would suppose that the worlds of anthropology and colonialism, in a fieldwork situation, had to be put together against the grain. But how?

Fonseca Cardoso's scientific interests were focused on Portugal. But intentions and projects can change by force of circumstance. It seems probable that Fonseca Cardoso, after the disappointment of having to abandon his project in Portugal, thought of shifting his allembracing French anthropological programme to Goa. He could move from his planned programme of national ethnogeny to Topinard's recommended study of the savage races on earth, particularly those under risk of extinction by colonial contact with European civilization and conquest - as would be those so-called 'terrible' Ranes and tribal people of Satari. He was also probably eager to profit from the technical wonders of the French anthropometric instruments he had so recently received from Paris. Thus, he would not travel to Goa alone. He carried Topinard's anthropometrical box in his baggage. However inconvenient to his purposes in the anthropometry of Portugal, the imperial event would now be transformed into the site of anthropological fieldwork.

But before directing our attention to fieldwork, let us observe the enactment of anthropology's connection to colonialism in the narrative of 'O Indígena de Satari'. The link between the scientific outcome and the colonial context of the Goan revolt, as well as their 
accommodation to Topinard's anthropological method, was established in Cardoso's introductory words to 'O Indígena de Satari':

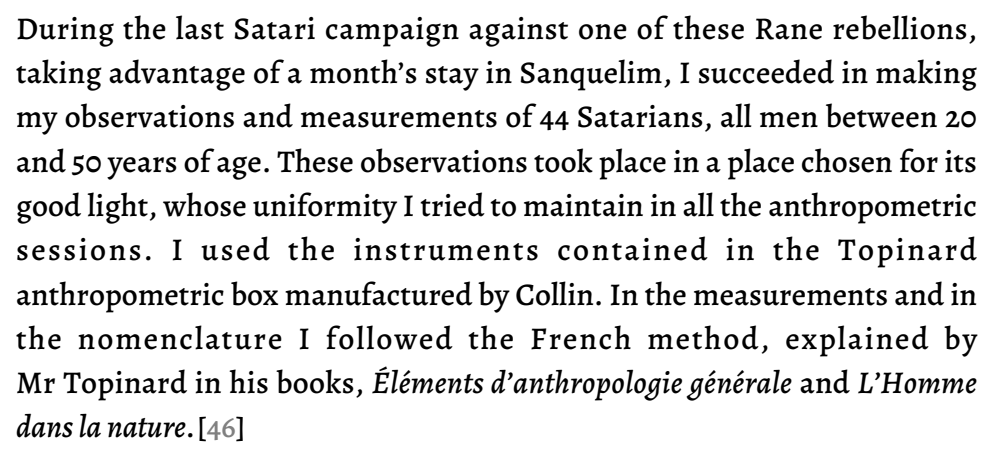

Here the connection between text and colonial campaign serves, significantly hand in hand with the reference to Topinard's tutorial method, more as a literary strategy for asserting anthropological authority and scholarly honesty than as a prelude to an effective link to imperial projects and events. It confirms for the reader the author's actual face-to-face presence with the objects of study, and testifies to the reliability of the results, being true descriptions of the Satarians taken directly from work in the field. [47] Any mention of other circumstantial information is omitted. Cardoso's anthropological narrative, contrary to the travelogue style (which was fanciful and highly subjective), was similar to Topinard's objective method. Contextual elements helped to set the temporal and spatial stage of the experiment or travel observation. Scientific writers were expected to be objective and observe the conventions set by Topinard's méthode anthropométrique and méthode descriptive. [48] Supported by a wide array of classification charts and mathematical indexes, both methods were meant to eradicate the subjective travelogue style from anthropologists' scientific descriptions. Cardoso's account, therefore, included systematic accounts of anthropometric indexes, statistical calculus, a brief account of indigenous morals, crossreferences to other bibliographies, and comparative charts of anthropometric measurements of the forty-four Satarians under observation. Apart from that strategic rhetorical reference, Cardoso found no interest in connecting his text to empire, war, pacification or colonial politics. It attempted to study the essentialist racial representation of the Satarians without taking into account colonial implications, making it a piece of 'pure' anthropological science. In the text colonialism and anthropology in Goa were merely two loosely connected stories.

But one can follow that short reference, and try to reconstruct the text's colonial connection back to less literary and more material locales, and one can attempt to understand how anthropology and colonialism could become mutually and intensely embedded in the fieldwork practices of Fonseca Cardoso during the Goan revolt. Again, it should be stressed that this embeddedness was not preconceived by any participants in or programmes of imperial expansion. It was not in the minds of imperialists on the expedition, of politicians in the metropolis, or even considered by Cardoso himself until much later. Moreover, as we have seen above, the general balance of power between invaders and natives clearly did not 
benefit the Portuguese, which meant that, generally speaking, conditions for anthropological study were not propitious. Colonial power in Satari was certainly about violence, but not about hegemony. Thus the proper power environment for anthropometric practice had to be made against the grain of colonial events by laborious practices.

To this observation one should add that there were particular problems taking anthropometric measurements. Anthropometry was a difficult, time-consuming and meticulous practice involving the assemblage of large numbers of living people whose bodies had to assume very specific and standardized positions in order to be measured accurately: specific measurements were needed for breasts, arms, legs and head. Subjects were forced to be quiet, to be obedient during examination, and to submit to a series of manipulations by the anthropologist and his assistants. From experience anthropologists had found that prisoners, soldiers, children and medical patients, in fact people in a subordinate position in the balance of power within modern disciplinary institutions, suited perfectly their needs. Overseas explorers, however, confronted by unknown territory did not have the benefit of the sort of power-knowledge apparatus Foucault ascribed to such disciplinary institutions. [49] Paul Topinard was conscious of that. He noted in 1885 that travellers 'can find themselves in two distinct situations: either well settled and able to bring the indigenous into his office or tent [. . .]; or in movement, trading with the savages, and having no time to domesticate the latter who refuse to be measured by the instruments and to remove their clothes'. [50] One can thus imagine that anthropological observers overseas such as Cardoso had no easy task. In the turmoil of a seemingly unsuccessful military campaign and lacking the secure institutional surroundings for the recruitment and domestication of savage bodies for anthropometric purposes, study was extremely difficult.

It is not possible to uncover the exact circumstances of the anthropological study at Satari from available documents. [51] However, partial accounts enable me to infer some of the circumstances of the anthropometric situation. How could Cardoso have obtained and domesticated forty-four Satarian men in that specific colonial context? I presume that he could have studied Satarian prisoners of war, when available. They were ideally suited to anthropometric requirements for domesticated bodies. Furthermore, prisoners of war were also important as a means to acquire information through interrogation or to punish. Prisoners of war were also supposed to epitomize what imperial imagination thought Satari subjects should turn into: passive, obedient, manageable and governable bodies and souls. In Goa, Cardoso needed Satarians and Ranes to measure as much as the imperial expedition needed Satarians to fight, capture and punish. The question remains as to how governable subjects could be enlisted. The general context of the campaign did not help. Few, if any, prisoners were captured; in fact, as we have seen above, the army was barely capable of locating its enemies. Possibilities for anthropometric domestication were, thus, extremely limited at best.

Apparently Cardoso took advantage of unusual and hazy circumstances. The only account of the capture of a considerable number of natives which I have come across was by Cardoso 
himself. In December 1895 he was in command of a small force responsible for one of the very few examples of good fortune: the capture and imprisonment of eighty Satarians. Encamped in the woods at night, the group was surprised in an ambush set by Cardoso and his men. The attack was planned as result of information received from a colonial district administrator. Men, women and children innocently gathered around a fire were surprised by soldiers who stormed the place in a panic, shooting off their guns. Cardoso tried to stop the shooting. In his official report to Infante D. Afonso he described the events and the violence involved in the capture of prisoners:

In order to stop as much as possible the escape of the natives who we were now sure were bivouacked at the point indicated by the glare [of a bonfire], I ordered Sergeant Sousa to go left, with Guide Corporal Lopes, so as to round up the indigenous group and push them towards my side, where I would then receive them in the open countryside, which was more favourable for the arrest. [...] Sergeant Sousa's force fired a few shots to my great surprise, accompanied by shouts of 'grab them, grab them', surround them, surround them', which were repeated all along the line. In spite of this I shouted 'cease-fire', which was supported by all the sergeants [...] I arrived in time to prevent the firing from continuing, and only eight shots were fired. On the spot, my force naturally divided into as many groups as there were natives who could not escape, surrounding them. [52]

One soldier and a native were wounded; an old man and a girl were killed by Portuguese gunfire. The remaining indigenous people were taken to the Sanquelim fortress by forced march through the night, 'which was carried out with difficulty and painfully because of the poor quality, dark road and the large number of prisoners, men, women and children'. [53] Presumably, the expedition had finally captured a significant number of fierce rebels. But this was not the case. In a letter which appeared in the newspaper O Aurora do Lima in 1896, Cardoso included more information on the prisoners' identity and commented on the accuracy of intelligence. Rather than standing as proof of the efficiency of the colonial intelligence service, the event actually testified to its failure. The imprisonment of natives resulted from the errors and uncertainties of the service. The morning after their arrival at Sanquelim fortress, Cardoso was informed that the prisoners were innocent people:

At one o'clock at night, the force entered Sanquelim, leading 80 prisoners, of whom 44 were men, who were taken to the Sanquelim fort. At dawn the next day, it turned out that these people were working on the road that was being built to Bicholim. The unforgivable carelessness of the administrator of the municipality, who, knowing about the bivouac of those people in a country that was at war, did not warn the headquarters, was the cause of that bad incident. This person of authority, who was incapable of doing his job, has fortunately been dismissed from his post. (my italics) [54]

The eighty prisoners, among them forty-four Satarian men, the precise number Cardoso later submitted to anthropometric observation, were poor, humble workers who had simply taken a much deserved rest after a hard day constructing a road to serve the colonial state in 
Goa. In Fonseca Cardoso's own words the colonial success was indeed an equivoque of empire. What looked like a victory was in fact a terrible mistake. They were not enemies; they were neither rebels nor Ranes. One could go further and wonder whether these presumed 'Satarian natives' were not villagers from neighbouring provinces instead of Satari residents. Many Satari villages had been deserted and these people may have been hired from other districts by colonial officials for the purpose of constructing the road. Believing those forty-four prisoners to be the same forty-four measured by Cardoso presents a strikingly equivocal, and certainly ironic, situation of entanglement between anthropology and colonialism. An entanglement, moreover, that had to be worked out. Imprisonment had to be transformed into the anthropological domestication of living bodies; prisoners into anthropological subjects; military forts and colonial prisons into anthropometric laboratories.

One can therefore imagine Fonseca Cardoso taking advantage of these ambiguous and absurd imperial circumstances, blurring anthropological interests and instruments with colonial moments and military materials. Because of his previous experience with military anthropology in northern Portugal, Cardoso was able to train his men to help in the production of anthropometric data. And Cardoso was able to juggle his military duties with anthropometric studies. Along with the anthropometric box and his anthropometric skills, military and colonial elements formed a hybrid assemblage for producing anthropological field notes. Upon closer examination one could say that the worlds of anthropology and colonialism were connected. Interestingly, this anthropological occasion was itself both ambiguously anthropological and imperial: both an instance of imperial pacification of recalcitrant Satarians, and an instance of the anthropometric discipline of human bodies. Anthropology and colonialism emerged as connected, however equivocally, in the production of ' $O$ Indígena de Satari'. But not for very long and not in the same way.

\section{Diversions of an Intellectual Artefact: Audiences and Appropriations of 'O Indígena de Satari'}

As noted above, Cardoso's reconstruction of the colonial occasion in the narrative of ' $O$ Indígena de Satari' did not allude to the paradoxical and heterogeneous circumstances of its material production. In the text he describes an anthropological investigation carried out according to French methodological conventions. I have tried to reconstruct those circumstances from other documents where Cardoso himself gave detailed accounts of his participation in the imprisonment of Satarian subjects, which I believe he tactically translated into an occasion for the anthropometric study of captive bodies. The bodies of imperial prisoners were used as anthropometric subjects, numerically and literarily inscribed and later essentialized as racial types of Satari. Other diversions, however, would arise along with the contexts for using and interpreting both the text and Cardoso's biography.

First, let us situate the circulation of the text as regards Fonseca Cardoso's strategy to 
generate scientific credibility; and, second, place it in the context of Rocha Peixoto's strategy to earn Cardoso professional autonomy. [55] When Fonseca Cardoso returned to Portugal in 1896 he began transforming his Indian anthropometric field notes into a proper scientific anthropological narrative. He wanted to produce a purely scientific text, a work belonging to an international field of scholarship he identified as Indian anthropology. After his return from Goa, Cardoso put his Portuguese projects of 1894 on hold and focused on turning his anthropometric data on the Satarians into a publishable document. This shift in focus required some effort. The purpose of his new work was clearly expressed in a letter to Leite de Vasconcelos, in September 1896:

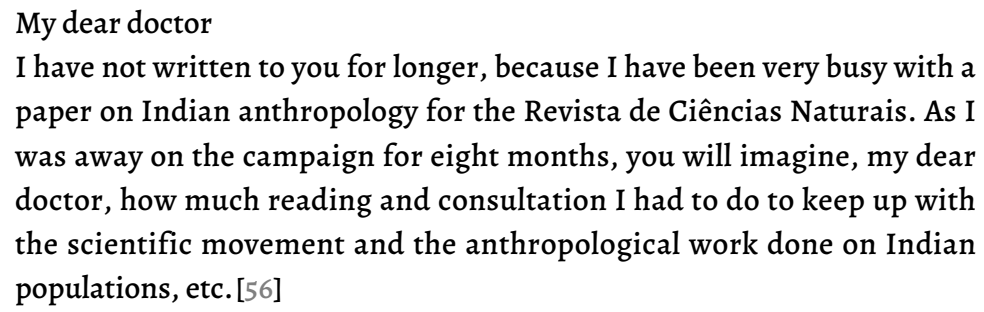

Cardoso refers to his involvement in the writing up of the article by mentioning how hard he has been working to update his readings. Cardoso's confession to Vasconcelos reveals the trajectory he initially conceived for ' $O$ Indígena de Satari'. It was not supposed to become a tool of colonial government, or the study of a discipline called 'colonial anthropology'. As a regular reader of French journals Cardoso saw himself contributing to an avant-garde field of orientalist research, centred in France, from which he could expect recognition for Indian anthropology. Indeed, the early years of the 1890 s saw the anthropometric study of native Indians emerging as central topic in several articles published in the leading French journal L'Anthropologie. However, this 'scientific movement', as Cardoso called it in his letter to Vasconcelos, was unknown (not to say irrelevant) to Cardoso prior to his journey to Goa, for he had not planned to be an anthropologist devoted to the study of colonial populations. After his return to Portugal it took him about four months to analyse his field notes and read a considerable number of scientific articles and monographs with which he was not yet acquainted. These, together with Topinard's tractatus of anthropology, would become the bibliography referred to in ' $O$ Indígena de Satari', and among them were Herbert Hoppe Risley's first volume of Tribes and Castes of Bengal, which had recently been published, and an extensive critical review of Risley by Topinard himself. [57] Topinard's critical reflections on Risley's work certainly caught the attention of Fonseca Cardoso, who eventually saw in his field notes on savage Satarians an opportunity to be welcomed into what he envisaged as the epicentre of anthropological authority - Topinard and the Parisian institutions. Thus, we should not be surprised that, when concluding his detailed anthropological description of the Satarians' anthropometric indexes, Cardoso was eager to corroborate Topinard and Risley's hypothesis on the racially mixed nature of Indian populations. [58] 'O Indígena de Satari' appears, then, at this point, as an attempt to accommodate Topinard's guidelines on emergent Indian anthropology and to capitalize on Cardoso's credibility as scientific author. 
Fonseca Cardoso's intent to situate his intellectual product was not successful. In the hope of laudatory reviews, he sent copies to French anthropological journals and to every Portuguese scientific society related to anthropological issues in the metropole. [59] He was concerned that the article be seen as a scientific artefact, and not as a tool of the colonial government, and for that reason he did not send it to the political and military authorities. But despite his efforts to place the article in both international and national scientific communities, ' $O$ Indígena de Satari' was virtually ignored by his anticipated readers in France and Portugal. Between 1896 and 1897, Portuguese journals more or less devoted to ethnological subjects simply did not mention the work. The Spaniard Hoyos Sainz, in an annual review of anthropology in Portugal and Spain, omits any reference to Cardoso's text. [60] Even Cardoso himself, in a later review of anthropology in Portugal, made no mention of his own article. [61] In France, only the Bulletin de la Société d'anthropologie de Paris mentioned the text in its monthly list of anthropological works. [62] In L'Anthropologie, where Portuguese anthropological publications were read and reviewed, there was not the slightest allusion to Cardoso's Indian work. The initial trajectory of ' $O$ Indígena de Satari' appeared very unsuccessful and unlikely to provide rewarding circulation and credibility for its author.

There were reasons for the silence from both Portuguese and French anthropological communities, however difficult they might be to discern. In respect of the French, and Topinard in particular, the indifference might have been because of its Portuguese origin (and language), which relegated it to the periphery of French interests; or its conclusions, however honest, may have been considered feeble and inconclusive replications of the method. Cardoso had presented a short, twelve-page article and only forty-four measured individuals to support his claim - scant evidence compared to Risley's five thousand measured Indians, and still very far from Topinard's declared minimum of at least one hundred individuals as standard for statistical significance. [63] As regards the emerging Portuguese ethnological audience, any anthropometric text on colonial populations had, on its own, little chance of success. Ethnologists, philologists and archaeologists remained exclusively focused on problems of national ethnogeny, automatically relegating colonial ethnological issues to the periphery of an emergent expertise - a 'periphery', by contrast, which gave more respect to the practical life of colonial officials, the military, or missionaries than to the community of ethnologists in Portugal.

A final fact may have reinforced the destiny of 'O Indígena de Satari', the difficult financial circumstances of the Sociedade Carlos Ribeiro and Revista de Ciências Naturais e Sociais, where the article was published. Members of the Sociedade were continually faced with the problem of getting the journal published. [64] It appears too that the journal did not make a positive impression on its (few) readers: 'We listened with dismay', wrote Peixoto, 'to the opinions of the public - restricted public! - through the collector: trivia! Things that no one understands! Only for the initiated!' [65] The Sociedade which had inspired so much enthusiasm on the part of Cardoso and his friends Peixoto and Severo in the 1880s was now in institutional distress. For a long while it had depended largely on private resources and personal good will, but eventually with Ricardo Severo's move to Brazil and Cardoso's long 
absence in Goa, its vulnerability increased. Indeed, the publishing of Cardoso's article in the last issue of the Revista was interpreted by Rocha Peixoto as the swansong of the Sociedade Carlos Ribeiro. [66]

There is only one instance where Cardoso's article merited enthusiastic mention in the early days of its circulation. And he owed this to his very good friend the ethnographer Rocha Peixoto, who early in 1897 wrote in praise of it in 'Anthropometry in the Army' in the military journal, Revista Militar. [67] Peixoto's evaluation of the work relied heavily on the personal bond of friendship that united him with Fonseca Cardoso, and which dated back to high school days and had been strengthened by the collective endeavour of the Sociedade Carlos Ribeiro. The way in which Peixoto interpreted this particular article is striking, and I presume Cardoso himself would not have disagreed with the interpretation. Scientific credibility was desirable in its own right, but 'O Indígena de Satari' could serve other more mundane personal interests. During his life Fonseca Cardoso experienced emotional stress in regard to his ambiguous professional identity. Though a soldier by vocation, Cardoso's passion was anthropology. He hoped to obtain in the army a professional position that would allow him to both provide a stable income for his growing family (he would father seven children) and realize his dream of becoming a full-time professional 'man of science'. [68] In his article, Rocha Peixoto addressed an audience of military readers and argued vehemently for the institutionalization of scientific anthropometry in the Portuguese army as a means of developing the anthropological study of the Portuguese, expand knowledge of ethnogeny and elevate a decaying national consciousness. He then proposed that his friend Fonseca Cardoso run the anthropometric services, for he considered him not only a most able soldier but a great anthropologist, as the recently published article 'O Indígena de Satari' clearly demonstrated:

This previously mentioned work ['O Indígena de Satari'], by army lieutenant Fonseca Cardoso, is the most confirmative document of a remarkable aptitude which is manifested with attendant evidence. Sober, rigorous, complete, considered, the study by the illustrious officer, already known for his palaeoethnological works, finally reveals to us his ability as an anthropometrist, as well as revealing to us the wisdom of his criteria, in view of the conformity of the results he obtained with those of Johnston, Risley and Topinard. [...] It is therefore to be hoped that, in the highest official bodies, where one of the most eminent figures of the army currently presides, this military man will be assigned to a service which, in addition to its importance and significance, will reflect one of the most praiseworthy and beneficial initiatives of this period in the country. [69]

While promoting anthropometry, Rocha Peixoto was also transforming an article ostensibly on Indian anthropology into a paean to Cardoso's anthropological skills, using it to convince those in authority of the need to offer Cardoso a post in the army to conduct anthropology studies in Portugal. The purpose was to get Cardoso a job as professional anthropologist. He would no longer have to fight savage and dangerous tribes in the colonies. He would stay in Portugal conducting anthropometric experiments in Minho as he had always dreamt of 
doing. But the attempt failed. Neither the military nor the politicians considered the proposal. Cardoso would have to continue as a captain if he wanted to provide a decent material living for his family. In fact the unsuccessful career of 'O Indígena de Satari' may explain why he never again published any of his anthropometric field notes on colonial populations. In Angola and Timor, where he would later serve, Cardoso also produced anthropometric fieldwork, but the notes were not published. [70] This neglect is in striking contrast to his investment in the anthropology of Portuguese populations after 1897 and up to his death in 1912. During these fifteen years Cardoso gained a reputation as an anthropologist of the Portuguese people, as the result of several published works on Póvoa de Varzim's fishermen and Castro Laboreiro's indigenous mountain communities in Portugal including, at last, his much cherished project on anthropometry in Minho. [71] His colonial field notes remained in a drawer.

When Fonseca Cardoso succumbed to malaria in Timor in 1912, he was by then well respected as an anthropologist specializing in Portuguese populations. He was not known as a colonial anthropologist, and the article ' $O$ Indígena de Satari' was little more than an inconsequential and anomalous hiccup in his public career as a scientist. However, this would now become transformed into a founding moment of the genealogy of 'colonial anthropology', as I noted at the beginning of this article. We are once again in the face of an equivocation, this time as part of the selective biographical appropriation of a man, and the intellectual artefacts attributed to him. This appropriation eclipsed the meaning Cardoso and his contemporaries attached to the artefact ' $O$ Indígena de Satari' and to his scientific identity as well. At this point we can easily understand how misleading was Cardoso's accommodation to the role of 'founder of colonial anthropology'. The reasons for this late genealogical transformation cannot be found in Cardoso's activities or texts. They call for a different context, for the specific professional strategies and interests of the generation of Portuguese anthropologists that succeeded Cardoso. In fact, these events should be understood in the context of Mendes Correia's attempts at personal career-building and the Porto anthropologists' collective effort to institutionalize a new discipline, gain the support of the state, and acquire authority over other professional competitors in the study of colonial populations. [72]

To explain: a good deal of responsibility for the selection of 'O Indígena de Satari' and Fonseca Cardoso as the foundation of Portuguese colonial anthropology can be attributed to António Mendes Correia, who was probably the most prominent figure in Portuguese anthropology in the first half of the twentieth century. [73] In the 1940s and '50s he became director of the main scientific research institutions in the colonies (for example, Junta das Missões Geográficas e de Investigações Coloniais, created in 1936), having convinced the powers that be of the importance of university-centred, state-sponsored anthropological research in the colonies. Yet in 1912, at the time of Cardoso's death, Mendes Correia was a young, unknown anthropologist (originally trained as a doctor) who had just been appointed assistant professor of anthropology at the Faculty of Sciences in Porto. Anthropology was a young academic science. It first found a place in the Portuguese universities' curricula in 1885, at Coimbra University, and only in 1911 in Porto. [74] Correia had never personally met 
Fonseca Cardoso, but was well aware of his work and reputation. Nevertheless, Fonseca Cardoso and his intellectual artefacts would play an important role in promoting Correia's professional career as colonial anthropologist.

At the time of Cardoso's unexpected death Mendes Correia had become a friend of one of Cardoso's sons. Young and ambitious, Correia probably knew he had a good opportunity to promote himself in the event that he acquired the unpublished anthropometric data recorded by Cardoso in Angola and Timor. With the financial support of his university, he gradually brought to his museum and office at Porto University the ethnographic collections, anthropometric instruments, books, manuscripts and field notes which had been in the keeping of Fonseca Cardoso's widow. [75] It did not take long for him to analyse and publish Cardoso's field notes as his own work, under the title 'notas antropológicas sobre observações de Fonseca Cardoso'. He successfully put the field notes to personal scientific profit and unlike Cardoso and ' $O$ Indígena de Satari', he earned a good deal of scientific credibility. Between 1916 and 1918 he published three articles on the anthropology of Timor and Angola, which were enthusiastically acclaimed in journals in Portugal and abroad, [76] including, with no little irony, the French journal L'Anthropologie. [77]

By the late 1910s, Mendes Correia had become the official voice of Cardoso's scientific life, and in 1919 he quite naturally selected Cardoso as the symbolic patron of a new anthropological society headed by himself, the Sociedade Portuguesa de Antropologia e Etnologia. His professional appropriation of Cardoso as the main figurehead of 'colonial anthropology' as a scientific discipline in Portugal in the 1930s was particularly impressive. 1934 was an important year for anthropologists and advocates of the empire in Portugal. Politically, the country had shifted to a nationalist authoritarian right-wing regime under the presidency of Salazar, who strongly supported imperialist ideologies. Scientifically, the first big colonial exhibition of Portuguese imperial possessions, the $1^{\mathrm{a}}$ Exposição Colonial Portuguesa, was held in Porto. Anthropology was well represented in this event by Mendes Correia and his acolytes at Porto University. For the first time around three hundred living specimens had been sent to Portugal from Angola, Mozambique, S. Tomé, Cape Verde, Timor and Goa, and many were measured and studied in the anthropological laboratories of Porto University. [78] Physical anthropologists were content. Their authority had finally found state legitimacy. Even the press and the general public seemed interested in following the exhibition and listening to the informed discourse of university anthropologists. [79] The First Congress on Colonial Anthropology held in Porto as part of the exhibition's official events was a corollary of the professional victory of Mendes Correia and Porto's academics.

Academics were designing a discipline that would aid the colonial government, but they had competitors. A wide range of practitioners and traditions of anthropological knowledge traditions such as ethnography, ethnology, or linguistics; practitioners such as missionaries, medics, colonial officials and the military - existed and were represented at the conference. Correia and his academic collaborators were trying to win professional and epistemological superiority over a field of enquiry historically dominated by a heterogeneous world of 
colonial practitioners - the military, missionaries, officials, and doctors. [80] They needed a symbol to legitimize the field and their professional dominance of it. In their attempt to conquer a hegemonical status in the heterogenous and competitive Portuguese field of ethnographic and anthropological knowledge of the non-European natives, Mendes Correia and his group adopted Cardoso as a totemic tool of social and professional power. Fonseca Cardoso was not casually selected as the forefather of their lineage. He was a Portuguese scholar and a student of colonial peoples, a reputed scientist, a citizen of Porto, and a practitioner of anthropological methods in the lineage of Broca and Topinard. Thus, we finally arrive at the most enduring and reductionist of the equivocal translations of Fonseca Cardoso: his role as forefather of the Portuguese study of indigenous people and figurehead of a new group of anthropologists.

\section{Conclusion}

There is certainly a good deal of specificity involved in this case study, such that we cannot simply transfer it to other empirical situations. Cardoso's French-modelled anthropology, for instance, is not representative of the forms of knowledge of other Portuguese practitioners of anthropological knowledge excluded by Mendes Correia's narrative colonial officials, the military, missionaries, travellers, etc. These in fact had been a regular source of information on overseas native populations since at least the nineteenth century. But there is much we can learn in general about anthropology and colonialism from this specific narrative, and from the viewpoint of a practical history of anthropology as production, consumption and circulation. From Fonseca Cardoso's story we learn that the association between anthropological texts and colonial processes, which so many have identified as a steady historical link, is actually a complex process of associations and dissociations. Connections between anthropology and colonialism throughout the life of a text and its author are, therefore, in flux, being made and unmade in the practical process of production-consumption. Once its genealogical characteristics are removed, the story of Fonseca Cardoso and his intellectual artefact ' $O$ Indígena de Satari' offer the possibility for imagining the relationship between anthropology and colonialism as constantly in flux. Thus the career of Fonseca Cardoso and 'O Indígena de Satari' in Portuguese colonial anthropology provides grounds for the hypothesis developed in this essay. That is, so far as we can follow the unsteadiness of texts as intellectual artefacts along their routes of production and circulation, anthropology and colonialism are partially connected, as this case study dramatically reveals, through the contingent, temporary and unstable outcome of a sequence of practices of translation. In the case of Fonseca Cardoso, these translations were born out of equivoques, which, on the one hand, stem from circumstantial events that either blocked or paved the way for certain courses of action and tactical appropriations of material elements; and, on the other, were a result of strategic appropriations of Cardoso's biography and his intellectual artefacts as tools in a struggle for professional power and the institutionalization of a scientific discipline.

Cardoso's colonial anthropology was partial and ambiguous, but was also emergent in time 
and in practice. His life oscillated between the colonies and Portugal, driven by both his responsibilities towards a large, dependent family, and by his passion for scientific projects of anthropology at home, and affected by the contingencies of imperial expansion in which he was an active participant. The producing of 'O Indígena de Satari' was involved in these tensions. I have limited my analysis to the process of its circulation between the 1880 s and 1934. Within this period we can see that colonialism and anthropology were not equally and continuously connected at every moment in the story of Cardoso's text. There were times when and where that connection was very ambiguous. The relationship of colonialism and anthropology embedded in the history of Cardoso and 'O Indígena de Satari' was not stable. It moved whenever the focus was adjusted to examine a different context, or different participants' motives and programmes. It moved whenever we took different narratives and material occasions. The text, the situations of its practical production, the interests and motives of its author, and the groups of participants involved in the interpretation and material production of the text were not themselves stable. They changed. And once these changes occurred, the character of the text and its association with colonialism changed accordingly. Dis/connections between anthropology and colonialism were produced by the participants themselves, such that an unpredictable, uneven and sometimes ambiguous accomplishment of practices resulted.

At times Cardoso's anthropology was colonial; at times it was not. During fieldwork in India it was important to connect anthropological practice to colonial events, otherwise indigenous bodies would not be available for measurement. But during the construction of the narrative for presentation to an anthropological audience, the colonial experience was of no importance, only the scientific data mattered. When attempting to use ' $O$ Indígena de Satari' as a rhetorical tool to obtain a professional position, the text was turned into an example of the anthropology of the Portuguese people; here colonial connections were once more overlooked in favour of an anthropological programme focused on Portugal. At other times (as in the genealogical tale of the 1930s), its entanglements with the empire were strategically overemphasized to support the professional interests of a group of anthropologists in Porto; it was then necessary to link state and science in a common enterprise of knowledge. Here, Fonseca Cardoso and 'O Indígena de Satari' were appropriated to serve as the origins of a desired stable connection between anthropologists, anthropological knowledge and empire-building. The genealogy of Portuguese colonial anthropology was a totalizing and teleological interpretation, one deliberately chosen to suit the professional purposes of Mendes Correia and his academic followers at Porto University, such that a story of partial connections and sequential equivocal events was solidified into a single reality. However, as I have tried to identify the inconsistencies of Fonseca Cardoso's story in its relation to the colonial experience, the Porto anthropologists were wrong. And in being wrong, Cardoso and 'O Indígena de Satari' confront today's historians with a contradiction: colonial texts, or rather texts embedded in colonial situations, may only be partially colonial. They may entail throughout their ever-precarious cross-contextual story a rather complex set of other linkages with professional interests, personal emotions, 
materiality, scientific strategies, nationalist ideologies, ethnogenic programmes of knowledge, etc. Certainly other accounts of the circulation of texts as artefacts might reveal more about the significance of partiality and equivoques in the connections between anthropology and colonialism. But we should be prepared to deal with that paradox, so clearly inscribed in Fonseca Cardoso's story. Colonial anthropology is not - at least not on every occasion - colonial.

[1] Acknowledgements: This essay was originally published in Portuguese Studies, vol 19, (2003), pp. 80-19. I am grateful to the editors of Portuguese Studies for permission to reproduce it in BEROSE. I thank warmly the directors of BEROSE, Christine Laurière and Frederico Delgado Rosa, for their careful editorial support.

[2] Anthropology and the Colonial Encounter, ed. by Talal Asad (London: Ithaca Press, 1973).

[3] George W. Stocking, Jr, 'Colonial Situations', in Colonial Situations. Essays on the Contextualization of Ethnographic Knowledge, ed. by George W. Stocking, Jr (Wisconsin: University of Wisconsin Press, 1991), p. 4. This statement was reinforced in 1992, in his The Ethnographer's Magic and Other Essays in the History of Anthropology (Wisconsin: University of Wisconsin Press, 1992), p. 213.

[4] Compare Alfredo Margarido, 'Le colonialisme portugais et l'anthropologie', in Anthropologie et Impérialisme, ed. by Jean Copans (Paris: Franc, ois Maspero, 1975), pp. 307-44; Mário Canova Moutinho, 'A etnologia colonial portuguesa e o Estado Novo', in O Fascismo em Portugal. Actas do Colóquio realizado na Faculdade de Letras em Março de 1980 (Lisbon: Regra do Jogo, 1982), pp. 415-43; Rui Pereira, 'O desenvolvimento da ciência antropológica na empresa colonial do Estado Novo', in O Estado Novo - das origens ao fim da autarcia, ii (Lisbon: Fragmentos, 1986), 89-101; Donato Gallo, Antropologia e Colonialismo. $O$ Saber Português (Lisbon: Heptágono, 1988); Rui Pereira, 'A questão colonial na etnologia ultramarina', Antropologia Portuguesa, 7 (1989), 61-78; Jorge Freitas Branco, 'Cultura como ciência? Da consolidação do discurso antropológico à institucionalização da disciplina', Ler História, 8 (1986), 75-103. For a more critical view, see: Rui Pereira, 'Colonialismo e antropologia: a especulação simbólica', Revista Internacional de Estudos Africanos, 10-11 (1989), 269-81.

[5] Colonial Ethnographies, ed. by Peter Pels and Oscar Salemink: History of Anthropology, special issue, 8 (1994); Colonial Subjects. Essays in the Practical History of Anthropology, ed. by Peter Pels and Oscar Salemink (Ann Arbor: University of Michigan Press, 1999); Anthropology and Colonialism in Asia and Oceania, ed. by Jan Van Bremen and Akitoshi Shimizu (Surrey: Curzon, 1999). See also Patrick Wolfe, Settler Colonialism and the Transformation of Anthropology. The Politics and Poetics of an Ethnographic Event (London: Cassell, 1999).

[6] George W. Stocking, Jr, Race, Culture and Evolution. Essays in the History of Anthropology, 2nd edn (Chicago: University of Chicago Press, 1982), pp. 1-13.

[7] Peter Pels and Oscar Salemink, 'Introduction: Five Theses on Ethnography as Colonial Practice', History of Anthropology, 8 (1994), 1-34; Pels and Salemink, 'Introduction: Locating the Colonial Subjects of 
Anthropology', in Colonial Subjects, pp. 1-52.

[8] 'Introduction: Locating the Colonial Subjects ....' In support of this argument see Nicholas Thomas, Colonialism's Culture. Anthropology, Travel and Government (Cambridge: Polity, 1994).

[9] Excluded Ancestors, Inventible Traditions. Essays Toward a More Inclusive History of Anthropology, ed. by Richard Handler (Madison: University of Wisconsin Press, 2000); Jan Van Bremen and Akitoshi Shimizu, 'Anthropology in Colonial Contexts: A Tale of Two Countries and Some', in Anthropology and Colonialism, pp. 1-10; Eyal Ben-Ari, 'Colonialism, Anthropology and the Politics of Professionalization. An Argumentative Afterword', in Anthropology and Colonialism, pp. 382-409. For critiques of disciplinary views of the history of Portuguese anthropology, see Diogo Ramada Curto, 'Contributions to a History of Criminal Anthropology in Portugal', Portuguese Studies, 14 (1998); Ricardo Roque, Antropologia e Império: Fonseca Cardoso e a Expedição à India em 1895 (Lisbon: Imprensa de Ciências Sociais, 2001), pp. 281-343.

[10] 'Introduction: Locating the Colonial Subjects ... '

[11] 'Introduction: Five Theses ...', p. 17. I have elaborated on a similar point in Roque,

Antropologia e Império, pp. 237-43.

[12] Following James Clifford, préterrain refers to the 'hybrid spatiotemporal relationships that preclude the work of ethnography'. 'Introduction: Five Theses ..., p. 13. This conceptual sequence of material mediations on ethnographic production, are said to apply to a study of ethnography 'as a practical rather than an ideal method or a text' (pp. 12-19). See also Peter Pels, 'The Construction of Ethnographic Occasions in Late Colonial Uruguru', History and Anthropology, 8 (1994), 321-51.

[13] The fact that an analysis of the colonial entanglement of anthropological texts and occasions seems unsatisfactory when not taking into account trajectories of consumption is addressed by Han F. Vermeulen in his comparative study of two eighteenth-century ethnographic expeditions, which had quite different histories in the way they were and were not used by colonial governments: 'Anthropology in Colonial Context. The Second Kamchatka Expedition (1733-1743) and the Danish-German Arabia Expedition (1761-1767)', in Anthropology and Colonialism, p. 29.

[14] Anto' nio Mendes Correia, 'A obra anthropologica de Fonseca Cardoso', Dyonisos, 1 (1913), 29-32. See also, Correia, 'A sua obra scientifica', A Póvoa de Varzim, 5 (1916). Cardoso's biography of the Congress echoes Correia's versions of it in the 1910s. See: Alfredo Ataíde, 'Fonseca Cardoso e a Antropologia Colonial', in Trabalhos do $1^{\circ}$ Congresso Nacional de Antropologia Colonial (Porto: Edições da $1^{\text {a }}$ Exposição Colonial Portuguesa, 1934), pp. 151-56

[15] Joaquim Pires de Lima, 'Estudos de Antropologia Colonial — o que temos feito e o que precisamos fazer', in Trabalhos do $1^{\circ}$ Congresso Nacional de Antropologia Colonial, pp. 105-33.

[16] Artur da Fonseca Cardoso, 'O Indígena de Satari. Estudo anthropológico', Revista de Sciencias Naturaes e Sociaes, 5 (1897), 7-19. An earlier leaflet version of the article was published as O Indigena de Satari. Estudo anthropologico (Porto: [n.pub.], 1896). 
[17] In this paper I use the word 'anthropology' as it would have been meant in the late nineteenth and early twentieth century. The definition of anthropology predominating in Portugal in the first half of the twentieth century approximates the idea of 'physical anthropology' as we now conceive it. In the late nineteenth and early twentieth century, the academic institutionalization of anthropology in Portugal followed the French model. The school of Paul Broca understood anthropologie to be a broad scientific discipline embracing physical anthropology, ethnography and archaeology, but with the emphasis on racial and physical features. Fonseca Cardoso and Mendes Correia, although separated by a generation, shared a close understanding of anthropology in those terms.

[18] Compare Vermeulen, 1999.

[19] By the 1880 s the Portuguese colonial possessions included Angola, Mozambique, Guinea, and the islands of S. Tomé e Príncipe and Cape Verde (in Africa); Coa, Damão and Diu (in India); Macau (on China's coast); and East Timor (in Oceania).

[20] The separation of production and reception, a text and its contextual usage, is itself a conventional one. As historians and sociologists such as de Certeau and Chartier have argued, that same convention prevents us from thinking of consumers and readers as having an active role in the constitution of a text and its meanings. It also prevents us from imagining texts as having varied and contradictory appropriations, sometimes contrary to the author's intentions and the 'original' cultural context: Michel de Certeau, L'invention du quotidien (Paris: Gallimard, 1990), pp. 239-55; see also Roger Chartier, 'Texts, Printing, Readings', in The New Cultural History, ed. by Lynn Hunt (Berkeley: University of California Press, 1989), pp. 154-76.

[21] Signs of the complexity and partiality of this association can be found among some historians of anthropology. Talal Asad (followed by Vermeulen), for example, argued that colonial power had more influence on the destiny of anthropology than the reverse; even anthropology's relation to colonial contexts of power might have entailed more moderated intensity. Susan Bayly argues that, in respect of Indian ethnological enquiries, colonial racial scholarship was not simply about solving imperial problems; the 'full historical context' of these ideas is not found in imperial aims and strategies. Talal Asad, 'From the History of Colonial Anthropology to the Anthropology of Colonial Hegemony', in Colonial Situations, pp. 314-25; Susan Bayly, 'Caste and "Race" in the Colonial Ethnography of India', in The Concept of Race in South Asia, ed. by Peter Robb (Delhi: Oxford University Press, 1995), pp. 165-218. Compare Talal Asad, 'Introduction', Anthropology and the Colonial Encounter, ed. by Talal Asad, pp. 17-18; Vermeulen, pp. 17-18.

[22] On the idea of translation as I use it here, see Michel Callon, 'Some elements of a Sociology of Translation: Domestication of the Scallops and the Fishermen of St Brieuc Bay', in Power, Action and Belief. A New Sociology of Knowledge, ed. by John Law (London: Routledge \& Kegan Paul, 1986), pp. 196-233; Bruno Latour, The Pasteurization of France (Cambridge: Harvard University Press, 1993).

[23] 'Introduction: Five Theses ..., p. 17 (my italics).

[24] Donna Haraway, 'A Cyborg Manifesto: Science, Technology, and Socialist-Feminism in the Late 2oth Century', in Symians, Cyborgs, and Women. The Reinvention of Nature (London: Free Association, 1991), pp. 149-81; Marilyn Strathern, Partial Connections (Lanham, MD: Rowman \& Littlefield, 1991). See also Tiago 
Moreira, 'Translation, Difference and Ontological Fluidity: Cerebral Angiography and Neurosurgical Practice (1926-45)', Social Studies of Science, 3 (2000), 421-46.

[25] Strathern, p. xx.

[26] Elizabeth A. Williams, 'Anthropological Institutions in Nineteenth-Century France', Isis, 76

(1985), 330-39.

[27] Rocha Peixoto, 'A Sociedade Carlos Ribeiro. Nótula histórica', Revista de Sciencias Naturaes e Sociaes, 5 (1898), 189

[28] For the Sociedade Carlos Ribeiro and its links with France: Roque, 'Porto-Paris, ida-e-volta: estratégias nacionais de autoridade científica. A Sociedade Carlos Ribeiro e a antropologia portuguesa no final do século XIX', in Enteados de Galileu? A Semiperiferia no Sistema Mundial da Ciência, ed. by João Arriscado Nunes and Maria Eduarda Conçalves (Porto: Afrontamento, 2001), pp. 247-98.

[29] Biographies of Rocha Peixoto, in particular, are also instances of 'founding-father' genealogies of Portuguese ethnography and cultural anthropology. See AAVV, Boletim Cultural da Póvoa de Varzim. Número comemorativo do nascimento de Rocha Peixoto (Póvoa de Varzim: Câmara Municipal, 1966); Flávio Concs alves, 'Prefácio', in Etnografia portuguesa (obra etnográfica completa), Rocha Peixoto (Lisbon: Dom Quixote, 1967; repr. 1991), pp. xv-Ivii.

[30] The 'notion of race', according to Topinard, was 'entirely strange' to issues of nationality and ethnogeny. Paul Topinard, Éléments d'anthropologie générale (Paris: Delahaye et Lecrosnier, 1885), pp. 212-13. This is not to say that other leading figures (such as Broca himself) did not concern themselves with connecting anthropologie to ethnogenic problems, but that Topinard's version (which Cardoso followed) relegated problems of national character to the periphery of the science of anthropology. See, for example, Paul Broca, Mémoires d'anthropologie (Paris: Reinwald), i (1871), 277-334 and 385-430.

[31] Contrary to its colonial counterpart, the Portuguese bibliography of nineteenth- and twentiethcentury Portuguese anthropology as a study of the Portuguese people and popular culture is extensive. See Carlos Fabião, 'Archaeology and Nationalism: the Portuguese Case', in Nationalism and Archaeology in Europe, ed. by Marguerita Díaz-Andreu and Timothy Champion (London: University of College Press, 1996), pp. 90-107; Augusto Santos Silva, Palavras para um país: Estudos incompletos sobre o Século XIX Português (Oeiras: Celta, 1997); João Leal, Etnografias Portuguesas (1870-1970). Cultura Popular e Identidade Nacional (Lisbon: Dom Quixote, 2000). For a general view of the historical connection between the rise of humanist disciplines and nation-building, see Anthony D. Smith, National Identity (London: Penguin, 1991).

[32] For methodological and theoretical aspects of Topinard's programme see Race, Culture and Evolution, pp. 161-95; and Antropologia e Império, pp. 137-64.

[33] There are several historical examples in France and Germany of military information being used for anthropological purposes. Broca's studies on the ethnology of France, for example, relied on military anthropometric registers. Later René Collignon distinguished himself as an anthropologist by taking 
advantage of his position as a doctor in the French army. Collignon was one of Topinard's adherents and is referred to in Cardoso's work. Broca; Paul Topinard, 'Congrès des sociétés savantes. Une nouvelle entente internationale en anthropologie', L'Anthropologie, 3 (1892), 380-81; Fonseca Cardoso, 'Anthropologia do povo portuguez. O Minhoto d' entre Cavado e Âncora', Portugália, 1 (1898), 23-59.

[34] Museu Nacional de Arqueologia-Epistolário Leite de Vasconcelos (hereafter MNA-ELV): Fonseca Cardoso to Leite de Vasconcelos, Areosa (Viana do Castelo), 24 July 1893.

[35] MNA-ELV: Fonseca Cardoso to Leite de Vasconcelos, Viana do Castelo, 17 September 1894.

[36] Cardoso's dispatch to India was identified by Rocha Peixoto as one of the crucial reasons for the collapse of the Sociedade Carlos Ribeiro in 1898. Peixoto, p. 204.

[37] Sources are contradictory as regards the exact number of armed rebels. Comes da Costa mentions around 5,000 or 6,000 armed men, the governor-general of Goa refers to 1,500 rebels, and later Goan historian Gabriel Saldanha estimates between 800 and 900 armed men. Visconde de Vila Nova de Oure'm, A Revolta dos Marathas em 1895: analyse e considerações sobre os acontecimentos da Índia (Lisbon: Matos Moreira \& Pinheiro, 1900); Padre M. J. Gabriel Saldanha, História de Goa (política e arqueológica) (New Delhi,Madras: Asian Educational Services, 1925; repr. 1990), p. 1; Comes da Costa, A Revolta de Coa e a Campanha de 1895-1896 (Lisbon: Livraria Popular, 1939).

[38] Since the eighteenth century Goa had been divided into two separate and contrasting territories, as regards colonial state control. Coastal districts were designated as velhas conquistas ('old conquests'), meaning the provinces conquered by Afonso de Albuquerque in the sixteenth century, and subjected to systematic religious conversion to Catholicism, and to cultural, political, fiscal and economic influence and administration. The rest of the territory, by far the majority, was quite different. It was called novas conquistas ('new conquests'), and consisted of the territories incorporated by the Portuguese crown in the late eighteenth century after conflicts with the Marata kingdoms surrounding Coa. Imperial presence in these territories bore a marked contrast with that of the old conquests. The population remained predominantly Hindu, and the state administration of Panaji was barely capable of exerting any real control over daily life in the region. The best example of this sort of weak state and consensual colonial presence in the novas conquistas was perhaps the Satari province in north-eastern Coa.

[39] On the Ranes and their revolts since the eighteenth century, see Carmo Azevedo, 'The Revolts of the Ranas', Goa Today (1966), p. 19; Pratima Kamat, Farar Far. Local Resistance to Colonial Hegemony in Coa, 1510-1912 (Panaji: Institute Menezes Braganza, 1999).

[40] See Gonc alo Cabral, Índia Portugueza. A propósito dos acontecimentos de Satari (Porto: Magalhães \& Moniz, 1912); Oliveira Mascarenhas and Antunes Monteiro, Atravez dos mares. Recordações da Índia (Lisbon: Antiga Casa Bertrand, 1898).

[41] João da Câmara, 'Chronica occidental', O Occidente, 18 (1895), 233.

[42] Arquivo Histórico Militar (hereafter AHM)-India, 2nd Division, 5th Section, Expedition to India, 1895-96, Box 11, n. 4: 'Relatório dos confrontos de 19 e 20 de Dezembro de 1895. D. Afonso Henriques, 
Duque do Porto, para o Snr. conselheiro governador geral'. Compare Thomaz António Garcia Rosado, 'Expedição à Índia, 1895-1896', Revista do Exército e da Armada, 41 (1896), 162-65.

[43] Anonymous, 'Notícias da Índia (da carta de um expedicionário). Nova Goa, 10/1/1896', O Aurora do Lima, Viana do Castelo, 24 January 1896.

[44] Costa, p. 117.

[45] For a list of the rebels' claims: Kamat, pp. 224-25.

[46] Fonseca Cardoso, 'O Indígena de Satari', p. 8.

[47] For seminal arguments regarding silences and essentializations in ethnographic narratives see: James Clifford, The Predicament of Culture. Twentieth-Century Ethnography, Literature, and Art (Cambridge, MA: Harvard University Press, 1988), pp. 21-55; Edward Said, 'Representing the Colonized: Anthropology's Interlocutors', Critical Inquiry, 15 (1989), 205-25.

[48] Topinard, pp. 314-31.

[49] Michel Foucault, Surveiller et punir. Naissance de la prison (Paris: Gallimard, 1975).

[50] Topinard, p. 1137 (my translation).

[51] Although Cardoso kept a detailed diary of his travels in India and produced routine military reports, his several accounts do not mention anthropometry. His manuscript diary on Goa has only partially survived, ending on 5 December 1895. It is, however, likely that measurements were taken some time between 5 December 1895 and May 1896 (when Cardoso and the expedition returned to Lisbon). Compare Espo' lio dos Descendentes de Fonseca Cardoso (hereafter EFC): Artur da Fonseca Cardoso, Expedição militar à India, 1895. Notas de viagem, 10 November 1895 to 5 December 1895, Ms. notebook.

[52] AHM-India, 2nd Division, 5th Section, Expedition to India, 1895-96, Box 11, n. 3: 'Regimento de Infantaria no. 3. Sanquelim, 19 December 1895. Alferes de infantaria no. 3, Artur Augusto da Fonseca Cardoso'.

[53] AHM-India, 2nd Division, 5th Section, Expedition to India, 1895-96, Box 11, n. 3: 'Regimento de Infantaria no. 3. Sanquelim, 19 December 1895. Alferes de infantaria no. 3, Artur Augusto da Fonseca Cardoso'.

[54] Ruthar, 'Notícias da Índia. Pangim, 9 March 1896 (do nosso correspondente)', O Aurora do Lima, Viana do Castelo, 13 April 1896. Cardoso wrote regular accounts of the Goan campaign in the Minho newspaper under the pseudonym of Ruthar (an inversion of his first name, Arthur).

[55] The strategy of scientific authority and of credibility are discussed at length in Pierre Bourdieu, 'La spécificité du champ scientifique et les conditions sociales du progrès de la raison', Sociologie et Sociétés, 7 (1975), 91-117; and Bruno Latour and Steve Woolgar, Laboratory Life. The Construction of Scientific Facts, 2nd 
edn (Princeton: Princeton University Press, 1986).

[56] MNA-ELV: Fonseca Cardoso to Leite de Vasconcelos, Viana do Castelo, 20 September 1896

[57] Herbert Risley is among the major figures of Indian colonial ethnology, being responsible for the famous, and much discussed, ethnological census of India. The anthropometrical aspect of the state census was intended to be guided by Topinard's method and technologies, as Risley's private correspondence with Topinard testifies. However, in his review of 1892 Topinard criticizes Risley for not making proper use of his method. Accordingly, he stressed that the problem of Indian ethnical composition was not decided. Herbert H. Risley, Les tribus et castes du Bengale; Documents anthropométriques, 2 vols (Calcutta: 1891); Paul Topinard, 'L'anthropologie du Bengale ou étude des documents anthropométriques recueillis par M. Risley', L'Anthropologie, 3 (1892), 282-316. Also: Émile Deschamps, 'Les Veddas de Ceylan et leurs rapports avec les peuples environnants les rhodias et les singhalais', L'Anthropologie, 2 (1891); Charles Johnston, 'Race et caste dans l'Inde', L'Anthropologie, 6 (1895), 176-81. On Risley and Topinard, see Sekhar Bandyopadhyay, 'The Raj, Risley and the Tribes and Castes of Bengal', India Past and Present, 2 (1985), 41-52.

[58] Cardoso, 'O Indígena de Satari', pp. 12 and 19.

[59] EFC-Secretário-Ceral of Academia Real das Ciências de Lisboa to Mr Fonseca Cardoso, Lisbon, 11/1/1897. Other contemporary institutions and journals likely to have received Cardoso's article include Boletim da Sociedade de Ceografia de Lisboa, O Arqueólogo Português and Revista Lusitana (the latter two managed by his friend Leite de Vasconcelos), O Instituto (ed. by Coimbra University), Revista de Cuimarães (ed. by the Sociedade Martins Sarmento, where Cardoso and Severo had already published an article in 1889), Jornal de Ciências Matemáticas, Físicas e Naturais.

[60] L. de Hoyos Sainz, 'L'anthropologie en Espagne et en Portugal pendant l'année 1896', L'Anthropologie, 7 (1897), 737-38.

[61] Fonseca Cardoso, 'Anthropologia Portuguesa', in Notas sobre Portugal, (Lisbon: Exposição Nacional do Rio de Janeiro/Imprensa Nacional, 1908), 57-72.

[62] Anonymous, 'Périodiques (articles a signaler)', Bulletins de la Société d'anthropologie de Paris, 8 (1897), 259.

[63] Topinard, p. 314.

[64] MNA-ELV: Fonseca Cardoso to Leite de Vasconcelos, Viana do Castelo, 1 November 1892.

[65] Peixoto, p. 187.

[66] Peixoto, pp. 188 and 204.

[67] Peixoto, 'A anthropometria no exército', Revista Militar, 4 (1897), 97-104. Peixoto published several versions of this same article: 'A anthropometria no exército', Revista de Siencias Naturaes e Sociaes, 5 (1897); A 
terra portugueza (chronicas scientificas) (Porto: Livraria Chardron, 1897), pp. 135-43.

[68] Cardoso's resentment of Leite de Vasconcelos' successful professional trajectory from provincial doctor in Cadaval to state-supported ethnographer and director of the Museu Etnológico Português was stressed in several letters to Vasconcelos himself. MNA-ELV: Fonseca Cardoso to Leite de Vasconcelos, Viana do Castelo, 1 November 1892: 'Whenever I remember you, the good Dr. Leite, I say to myself as I consider my current living: I am doing the same as you are doing in Cadaval; shackled by the craft and tormented by the devotion of the brain. Ah, no one has materials and means for the accomplishment of his dreams like you, my good friend. At least that consoles me and your good letters and your good works make me happy.' Compare José Fortes, 'Nótula biográfica acêrca do capitão Artur Augusto da Fonseca Cardoso', O Archeologo Português, 18 (1913), 202.

[69] Peixoto, 'A anthropometria no exército', pp. 103-04.

[70] After his return from India, Cardoso remained in Portugal until 1902. Then, being promoted to captain, he joined a pacification expedition to Angola. In the aftermath of the conflict he was put in charge of Moxico district, inland Angola, as capitão-mór. He left the African colony in 1906 and returned to Portugal for only two years. In 1908, he was ordered to Timor, where he would assume several important positions in the colonial service, as military commander and governor's secretary.

[71] Cardoso, 'Anthropologia do povo portuguez'; Cardoso, 'Castro Laboreiro (ensaio anthropologico)', Portugália, 2 (1906), 179-86; Cardoso, 'O Poveiro. Estudo anthropologico dos pescadores da Póvoa de Varzim', Portugália, 2 (1908), 517-39. Cardoso's reputation as an anthropologist was acknowledged by his superiors in the army. AHM-File 1210: 'Processo individual do oficial Artur Augusto da Fonseca Cardoso'.

[72] Not everyone had a high opinion of Cardoso's contribution to 'Antropologia da Índia'. Coan doctor and physical anthropologist Alberto Cermano Correia referred to O Indígena de Satari as a mere, methodologically deceitful sketch, 'um esboceto somatométrico concernente a 44 indígenas de Satari'. Alberto C. Germano Correia, 'Antropologia da India', in Congresso do Mundo Português. Congresso da Actividade Científica Portuguesa (Lisbon: Comissão dos Centenários, 1940), p. 663; Correia, Índia Portuguesa. Estudos antropológicos e aclimatológicos (Nova Coa: Imprensa Nacional, 1918), p. 11. On the tension between Goan and Porto programmes see: Ricardo Roque, 'A antropologia colonial portuguesa (c. 1911-1950)',)', in Estudos de Sociologia da Leitura em Portugal no Século XX, ed. by Diogo Ramada Curto (Lisboa: Fundação Calouste Gulbenkian, 2006), pp. 789-822..

[73] On Mendes Correia, the development of Porto's anthropology and the rising of a new generation of cultural anthropologists under Jorge Dias's influence, see Rui Pereira, 'Introduc s a o a ' reedic s a o de 1998', in Jorge Dias, Os macondes de Moçambique (Lisbon: Comissão Nacional para as Comemorações dos Descobrimentos Portugueses/Instituto de Investigação Científica Tropical, 1998), i, v-lii; Roque, 'A antropologia colonial portuguesa'.

[74] See AAVV, Cem anos de antropologia em Coimbra (Coimbra: Museu e Laboratório Antropológico, 1985); A. Mendes Correia, Os estudos de antropologia na Academia Politécnica do Porto (1888-1911) (Porto: [n.pub.], 1937). 
[75] EFC-José Diogo Arroyo, Director of Faculdade de Ciências do Porto, to Armando da Fonseca Cardoso, 12 March 1915

[76] Mendes Correia, 'Antropologia Angolense. Quiocos, Luimbes, Luenas e Lutchazes. Notas antropológicas sobre observações de Fonseca Cardoso', Arquivo de Anatomia e Antropologia, 2 (1916), 323-56; Correia, Antropologia timorense (Porto: [n.pub.], 1916); Correia, 'Timorenses de Okussi e Ambeno (Notas antropológicas sobre observações de Fonseca Cardoso)', Annaes Scientificos da Academia Polytechnnica do Porto, 11 (1916), 36-51; Correia, 'Antropologia Angolense II. Bi-N'bundo, Andulos e Ambuelas-Mambundas. Notas antropológicas sobre observações de Fonseca Cardoso', Arquivo de Anatomia e Antropologia, 4 (1918), 283-321.

[77] R. Verneau, 'A. A. Mendes Corrêa, Timorenses de Okussi e Ambeno; e Antropologia timorense, 1916', L'Anthropologie, 27 (1916), 480-82.

[78] Compare Mendes Correia, 'Sessão solene de inauguração', in AAVV, Trabalhos do $1^{\circ}$ Congresso Nacional de Antropologia Colonial, i (Porto, $1^{\text {a }}$ Exposição Colonial Portuguesa, 1934), 21-29. Correia, O Instituto de Antropologia da Universidade do Porto e a investigação científica colonial (Porto, 1a Exposição Colonial Portuguesa, 1934)

[79] Porto's daily newspaper Jornal de Notícias, for instance, closely followed the congress and the anthropologists' observations on natives.

[80] There are grounds for comparison with Malinowski's forging of social anthropology in Britain by means of excluding colonial lay practitioners, a few years earlier in the 1920s. See 'Introduction: Five Theses ..., pp. 5-10. 